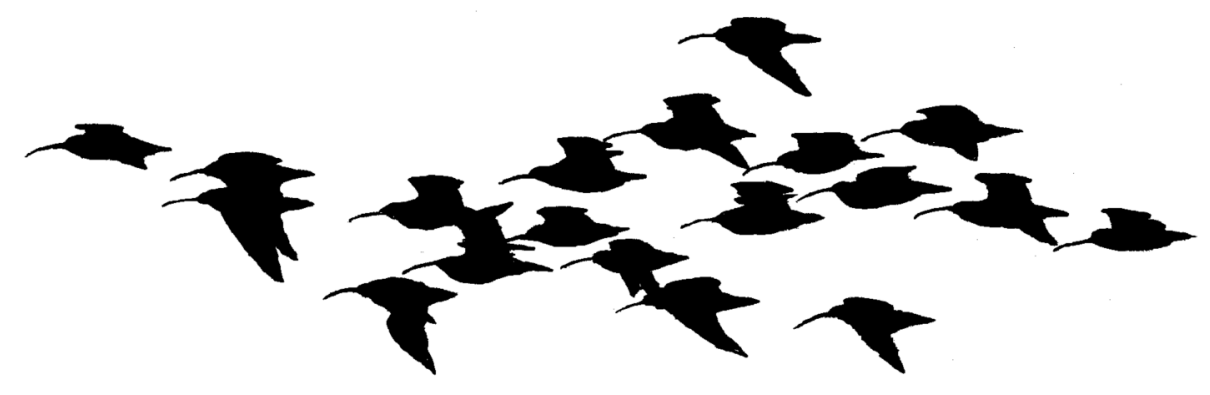

\title{
Ornithology from the flatlands
}

\author{
THE LOGIC TO QUESTIONS ABOUT BIRDS (AND OTHER TOPICS)
}

Why do House Martins Delichon urbicum prefer stinking old mud nests over clean strong artificial nests made of wood-concrete? Why do they choose the very nests that carry a load of louse fly Crataerina hirundinis pupae, parasites which as soon as they feel the warmth of returning martins will develop into serious bloodsucking monsters (Summers 1975, Piersma 2013)?

One could answer this question by suggesting that over the last few million years all ancestors of house martins have been using mud nests and that other nest types are simply not an option. One might hypothesize that during their development, young House Martins have learned to live in and love mud nests, so of course they will choose those over others, even if these alternatives are strong and clean. Perhaps House Martins love old mud nests because their presence signals a site where House Martins nested successfully in previous years; or perhaps the blood-sucking louse flies actually provide a benefit that we are unaware of? One could also suggest that the sight of an old mud nest (but not an artificial nest) makes the martins release the flush of love hormones necessary to prepare for mating and reproduction. Right. At this point, you will probably have recognized the four types of questions about animal behaviour distinguished for 'pragmatic' reasons by Niko Tinbergen (1963): on phylogeny, on development, on function and on mechanism. It is widely recognized that one should be clear about the kind of question (about a particular phenomenon) addressed in an idea or hypothesis, because without such structuring, the thinking is likely to be confused and arguments will never be settled.

Niko Tinbergen (1907-1988) was not the first 'Dutchman' to seek structure in the logic of asking questions (Tinbergen was born, raised and educated in The Netherlands, but moved, after an appointment in 1939-1947 at Leiden University, voluntarily resigning during the German occupation from 1942-1945, to the UK to become the professor of ethology at Oxford
University; see Bolhuis \& Verhulst 2009). Baruch de Spinoza (1632-1677), the Amsterdam-born son of Portuguese Jews seeking safety in The Netherlands from the Spanish inquisition, was somebody interested in structured thinking at a time when religion, and the particular social cocoons that religions resulted in, confined free-thinking. Importantly, Spinoza lived at a time when empirical knowledge was valued much less than logical reasoning; very often, life was simply too short to build-up empirical knowledge.

From his first work, "De verbetering van het verstand", or "The improvement of the understanding" (de Spinoza 1677, Curley 1985), onwards, Spinoza developed a structure to think, a structure that obviously reflected the range of ideas available to him at the time. During his own short and sober life, he practiced this structured logical thinking very systematically (Schuyt 2017). He thought about the relationships between rational thinking and emotions, about selfinterest and solidarity, and about personal and political freedom. Perhaps most critically, Spinoza thought that knowledge increases gradually, with nature only yielding its secrets little by little. The statue of Spinoza in Amsterdam made by Nicolas Dings (2008) shows House Sparrows Passer domesticus and Rose-ringed Parakeets Psittacula krameri in his mantle. This does not refer to any interest in ornithology. In Spinoza's time birds symbolized the free word. In the statue Ringnecked Parakeets, exotic newcomers to Amsterdam, symbolize tolerance; house sparrows stand for the decline of biodiversity.

Niko Tinbergen did most of his studies on birds and was probably not directly inspired by Baruch de Spinoza's attempts to improve the logic of thought. However, his own advice on the aims and methods of the study of behaviour, with the recognition of four types of questions, certainly inspired and guided a whole generation of ethologists. Also in the early 1960s, Ernst Mayr, again an ornithologist, wrote a review with 
a rather similar if somewhat expanded scope (Mayr 1961). In this paper Mayr created a distinction between 'functional biology' (the 'plumbing' of organisms, regarding DNA as the code of life, 'how') and 'evolutionary biology' (the study of organismal evolution at various time scales, 'why'). Note that in this dichotomy 'functional' is totally different from Tinbergen's use of the word; Tinbergen would say that functional biologists are interested in 'mechanisms'. However great the heuristic value of a distinction between the 'how' and 'why' questions may have been, according to Laland et al. (2011) it now hampers progress in biology. This is because the dichotomy fails to recognize the many feedbacks between traits, environments and gene expression, i.e. that the plumbing and evolution of organisms and their environments are so deeply (and so confusingly) intertwined. These are the dependencies that we now need to understand.

In his opus magnum "The study of behaviour. Organization, methods, and principles", Jerry Hogan (2017) recognizes the reciprocal feedbacks operating in nature. At the base of his arguments lies his conviction that cause and function are separate questions that both need to be answered (Hogan 2009). Also, whereas Tinbergen (1963) merged them in the category of mechanistic questions, for Hogan 'cause' and 'mechanism' are actually two distinct concepts. Mechanism is a structural concept: how does it work? How are the parts of the corporeal mechanism organized? Cause is what activates the mechanism. What sets the mechanism into action?

It can be argued that all questions about a behaviour like the House Martins' preference for old mud nests eventually boil down to questions about the history of that behaviour (Sapolsky 2017, Oudman \& Piersma 2018). Hogan (2017) acknowledges this, but nevertheless chose to categorize the types of questions as an aid to systematic logical thinking (Table 1). He systemizes his three 'Aristotelian' questions with respect to 'time' (current behaviour, ontogeny/individual development, and phylogeny/evolutionary history). The three basic questions, let's say about a wooden chair, are about 'structure' (Aristotle's formal cause: the chair has four legs, a seat and a back arranged in some special way), about 'causation' (Aristotle's efficient cause: the chair has been manufactured in this way by somebody) and 'consequence' (Aristotle's final cause: the chair has been made to sit comfortably). The framework encompasses Tinbergen's four questions, i.e. the one on phylogeny (questions on structure and causation under phylogeny, Table 1), on development (all three questions under ontogeny), on function (questions on consequence under phylogeny) and on mechanism (all three questions under current behaviour).

Table 1. A framework of the nine types of questions about behaviour as organized by Jerry Hogan (2017), and as it can be applied to the preference for old and self-(re)built mud nests by House Martins (a variety of questions are stated in italics).

\begin{tabular}{|c|c|c|c|}
\hline $\begin{array}{l}\text { 'ARISTOTELIAN' } \\
\text { CATEGORIZATION } \\
\text { OF QUESTIONS }\end{array}$ & current behaviour & $\begin{array}{l}\text { TIME SCALE } \\
\text { ontogeny }\end{array}$ & phylogeny \\
\hline structure & $\begin{array}{l}\text { What types of clay are used, } \\
\text { and how many clay-balls does } \\
\text { a mud nest comprise? What } \\
\text { are the perceptual, processing } \\
\text { and motor mechanisms } \\
\text { involved in the repair } \\
\text { or building of mud nests? }\end{array}$ & $\begin{array}{l}\text { In which ways does the 'neural } \\
\text { and hormonal wiring' in } \\
\text { House Martins change as } \\
\text { maturing individuals develop } \\
\text { the capacity to recognize and } \\
\text { to build and repair mud nests? }\end{array}$ & $\begin{array}{l}\text { How is the preference for old } \\
\text { mud nests and the association } \\
\text { with louse flies distributed } \\
\text { over the extant relatives of } \\
\text { House Martins and their } \\
\text { inferred ancestors? }\end{array}$ \\
\hline causation & $\begin{array}{l}\text { What are the internal and } \\
\text { external triggers that motivate } \\
\text { House Martins to repair or } \\
\text { build a mud nest? On what } \\
\text { basis do they recognize } \\
\text { the right clay types? }\end{array}$ & $\begin{array}{l}\text { Is the preference for old mud } \\
\text { nests, and the repair of them, } \\
\text { 'prefunctional'? What genes are } \\
\text { expressed during the building of } \\
\text { mud nests and does this differ } \\
\text { between environmental contexts? }\end{array}$ & $\begin{array}{l}\text { Was the use of old mud nests } \\
\text { always selected for in the past, } \\
\text { or only under particular } \\
\text { environmental circumstances? }\end{array}$ \\
\hline consequence & $\begin{array}{l}\text { During which times of year and } \\
\text { day do House Martins build } \\
\text { mud nests? Does a martin } \\
\text { feel happy after rebuilding } \\
\text { a damaged old mud nest? }\end{array}$ & $\begin{array}{l}\text { Is the inspection of empty } \\
\text { nests and nest remains } \\
\text { by fledglings important } \\
\text { in this learning process? }\end{array}$ & $\begin{array}{l}\text { Do House Martins using old } \\
\text { mud nests, or nests with more } \\
\text { louse flies, have higher fitness? }\end{array}$ \\
\hline
\end{tabular}


We can now go back to the seemingly odd preference of House Martins for old and self-(re)built mud nests stuffed with parasites, and freely ask questions about them (Table 1). The categorization of some of them helped me to begin understand the logic of thinking about birds as mastered by Hogan. As I pieced together Table 1, I came to realize that most of mainstream ornithology is devoted to only one out of nine of Hogan's categories. We mostly seem to publish on questions about what Hogan calls 'the consequence of behavioural phylogeny'. When we ask 'why', we ask about the function of a behaviour in terms of survival value and fitness benefits. Are the functional questions the easiest to answer? Or has it become time to expand our questioning minds?

\section{Acknowledgements}

The example of nest site choice in House Martins was chosen because Joop Jukema recently asked some pertinent questions about it, and because the present editorial was written during the spring days of their return to The Netherlands. I thank Jerry Hogan for many years of inspiration, and Kees Schuyt, Thomas Oudman, Rob Bijlsma and Jerry himself for feedback on a draft.

Bolhuis J.J. \& Verhulst S. (eds) 2009. Tinbergen's legacy. Function and mechanism in behavioural biology. Cambridge University Press, Cambridge.

Curley E. (ed.) 1985. The collected works of Spinoza, Vol. I. Princeton University Press, Princeton, N.J.
Hogan J.A. 2017. The study of behavior. Organization, methods, and principles. Cambridge University Press, Cambridge.

Hogan J.A. \& Bolhuis J.J. 2009. Tinbergen's four questions and contemporary behavioural biology. In: Bolhuis J.J. \& Verhulst S. (eds) Tinbergen's legacy. Function and mechanism in behavioural biology. Cambridge University Press, Cambridge, pp. 25-34.

Laland K.N., Sterelny K., Odling-Smee J., Hoppitt W. \& Uller T. 2011. Cause and effect in biology revisited: is Mayr's proximate-ultimate dichotomy still useful? Science 334: 1512-1516.

Mayr E. 1961. Cause and effect in biology. Kinds of causes, predictability, and teleology are viewed by a practising biologist. Science 134: 1501-1506.

Oudman T. \& Piersma T. 2018. De ontsnapping van de natuur. Een nieuwe kijk op kennis. Athenaeum, Amsterdam.

Piersma T. 2013. Timing, nest site selection and multiple breeding in House Martins: age-related variation and the preference for self-built mud nests. Ardea 101: 23-32.

Sapolsky R.M. 2017. Behave. The biology of humans at our best and worst. Penguin Press, New York.

Schuyt K. 2017. Spinoza en de vreugde van het inzicht. Balans, Amsterdam.

de Spinoza B. 1677. De Intellectus Emendatione Tractatus [Treatise of the emendation of the intellect]. In: Curley E. (ed.) The collected works of Spinoza, Vol. I, edited and translated by E. Curley. Princeton University Press, Princeton, N.J., pp. 3-45.

Summers R.W. 1975 On the ecology of Crataerina hirundinis (Diptera: Hippoboscidae) in Scotland. J. Zool., Lond. 175: 557-570.

Tinbergen N. 1963. On aims and methods of ethology. Z. Tierpsychol. 20: 410-433.

Theunis Piersma, University of Groningen \& NIOZ Royal Netherlands Institute for Sea Research 